Melina Pereira Savi

Universidade Federal de Santa Catarina, Florianópolis, Santa Catarina, Brasil

\title{
The Anthropocene (and) (in) the Humanities: Possibilities for Literary Studies
}

Abstract: This paper aims to briefly discuss the concept of the Anthropocene within the geological sciences, and to consider, more broadly, some of the theoretical unfolding of the term within the humanities. Towards its conclusion, the paper presents the demands the Anthropocene makes, as a geological Epoch (in which the human becomes a geophysical force, capable of changing the Earth's biophysical systems), of literary studies as a possible field for theoretical articulations that may add to the debates on this historical moment in which climate change, forced dislocations, the mass extinction of several species, and other urgent matters come to the fore. Keywords: Anthropocene; Climate Change; Humanities; Literary Studies.

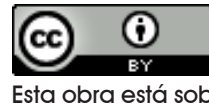

Esta obra está sob licença Creative Commons.

${ }^{1}$ This paper was completed with the scholarly counseling of Professors Claudia Junqueira de Lima Costa (the author's advisor) and Susana Bornéo Funck.

${ }^{2}$ http://quaternary.stratigraphy.org/ workinggroups/anthropocene/ ${ }^{3}$ Upon reaching a conclusion, the Working Group will submit their recommendations for consideration by the International Commission on Stratigraphy.
The Anthropocene, in its crudest definition, is the new geological Epoch we have entered, following the Holocene. The "anthropos" prefix aims at reflecting the idea that anthropogenic changes, that is, changes resulting from human actions on this world, are so large and ubiquitous that humans are now behaving as geological forces, playing a similar role as volcanoes, large meteors, earthquakes and the like. The precise moment when the Holocene became Anthropocene is still under discussion, and scientists belonging to the Anthropocene Working Group of the Subcommission on Quaternary Stratigraphy ${ }^{2}$ are expected to reach a conclusion on the subject soon ${ }^{3}$. Jan Zalasiewicz et al. (2014), for instance, suggest the moment when the first nuclear bomb was exploded, on July 16, 1945, at Alamogordo, New Mexico. The nuclear fallout resulting from this bomb and the subsequent bombs that were exploded at an average rate of one bomb every 9.6 days from 1945 to 1988 can be identified in what is called the "chemostatigraphic record," a measure used by geologists to analyze the chemical deposits in the strata. This boundary coincides with what has been termed 
"the Great Acceleration" of the mid-twentieth century, when we, humans, started using plastic at large, aluminum, and vast quantities of resources to keep up with the newly inaugurated Western model of production and consumption. Zalaziewicz's research group also proposes two other boundaries. The first is what they term the "early-Anthropocene", which dates back thousands of years, and the second one would coincide with the early stages of the Industrial Revolution, at around the 1800s. There are other research groups involved in the process of finding the "golden spike" that will mark the transition from the Holocene into the Anthropocene, that is, the optimal boundary marker for the transition of Epochs, Periods, and Eras. For now, the Anthropocene is a working term not only in geology but also in other realms of academic research, mainstream media and popular culture. In fact, in response to a piece entitled "Is the Anthropocene an issue of stratigraphy or pop culture?", written by Whitney J. Austin and John M. Holbrook (2012), with a tone of incredulity regarding the reach of the term into popular culture, Jan Zalasiewicz ef al. (2012) respond that:

We regard broader popular interest as positive. The Anthropocene has provided a longer-term perspective of humanity's activities and brings stratigraphic principles and practice to a wider audience. Also, the phenomenon of contemporary global changeperhaps unlike the formal determination of past geological time units-potentially concerns everyone.

This sort of "feud", if one could call it that, adds to the argument that the Anthropocene has reached diverse areas of debate, and in the pages to follow I attempt to address some of the unfolding of the term in the humanities.

For geologists, Zalasiewicz et al. (2014) explain, the Geologic Time Scale is the most important work tool they have, since it allows for the creation of a time framework encompassing the 4.6 billion years of the Earth's history. The strata, that is, the layers of rock that formed within this period of billions of years are analyzed having this time scale in mind. In them lie the cues to the creation of Epochs, Periods, and Eras boundaries. The strata, being the material evidence for the suggestion of boundaries, is still very recent in the Anthropocene, and Zalasiewicz et al. (2014) explain that for a boundary to be suggested and formalized, major changes to the Earth system must be identifiable in the rocks. These changes are indeed noticeable in them, they explain, and the scientific community has been exploring the evidences of the disruptions of Earth Systems in the rocks, in the atmosphere, in species diversity, in the acidification of the oceans and other places and spaces; thus the Anthropocene 
is already a working term among geologists, hard scientists, and Humanities scholars alike.

About strata, Jan Zalasiewicz (2008), in The Earth After Us, suggests a scenario where, 100 million years from now, when we are long gone (possibly, given our current climate change situation and business-as-usual approach to dealing with its threats), what possible future explorers would find in the strata as evidence of our existence. He contextualizes this scenario in an engaging way by presenting the following perspective: humans have been on this Earth for 250 thousand years. The meteor that is believed to have led the dinosaurs to extinction hit the Earth 65 million years ago. Dinosaurs inhabited the Earth for a $\mathbf{2 0 0}$ million-years period, and the Earth itself is 4.6 billion years old. Against the deep geological time of the world, our existence is nothing but meagre. But aside from exposing this awe-inspiring perspective, what Zalasiewicz does is to show how the Earth itself is registering the narratives of all that happens on its surface and what is expelled from its interior into the strata. The strata, in literary terms, is where the narrative of the world is written by time. The Earth, he puts it, "is a treasury of strata, a gigantic machine for producing strata that contain within themselves countless narrative possibilities of the histories of former oceans and rivers, of lakes and shorelines and arid deserts" (p. 17-18). It seems amazing how much the history of the Earth, in the way Zalasiewicz puts it, resembles everything we know for a fact about human and nonhuman lives. In the introduction to Material Ecocriticism, Serenella lovino and Serpil Opperman (2014) address this issue quite beautifully, by making a clear connection between the science of geology and nonhuman theory:

[...] the world's material phenomena are knots in a vast network of agencies, which can be 'read' and interpreted as forming narratives, stories. Developing in bodily forms and in discursive formulations arising in coevolutionary landscapes of natures and signs, the stories of matter are everywhere: in the air we breathe, the food we eat, in the things and beings of this world, within and beyond the human realm. All matter, in other words, is a 'storied matter'. (p. 1)

In this sense, rocks are not alone in registering the narratives of the world, since every human and nonhuman body is storied in the passing of time. One of the arguments Zalasiewicz puts forward is that it is indeed up to those who inhabit the world now the type of narrative we are willing to leave on the strata (or "weave" on the strata, in reference to Donna Haraway's formulations on cats' cradle and collaborations on storytelling, 2016). Will it be one that will resemble the event of the extinction of the dinosaurs, with the sudden rise in temperature and, perchance, ours and other 
${ }^{4}$ In the piece entitled "Anthropocene Capitalocene, Plantationcene Cthulucene: Making Kin", Haraway points out that the term was first used by Adreas Malm and Jason Moore before she started using it. The term, however, has been widely attributed to her since she started using it in public lectures from 2012 on. Haraway and Moore (editor) have published a book in 2016 entitled Anthropocene or Capitalocene? Nature, History, and the Crisis of Capitalism. species' extinction, or will humans be able to witness the arrival of the so-called explorers, 100 million years from now? That is not to say, however, that this narrative depends entirely on humans. A meteor led dinosaurs to extinction. Humans can have a similar, geologically-driven, fate.

The term Anthropocene has brought with it a number of contradictions. It has been criticized for its focus on the impact of human actions on the Earth by theorists such as Donna Haraway (2015), for instance, who have proposed alternative words such as "Capitalocene" 4 to convey the effects of capitalism as a system on the Earth instead of the effects of humans as a species, who are often alienated from the effects of their labors. Haraway (2014) accepts the word Anthropocene in the geological sphere, but believes that a term more representative of the system of extraction of energy, its uses, and the uneven distribution of wealth originating from it across the globe should be discussed in other realms of theorization. Dipesh Chakrabarty (2013) also problematizes the term by pointing out that humans do not burn fossil fuel or engage in other Earth disrupting practices evenly across the globe, but his argument differs somewhat from Haraway's. He reasons that although Capitalism does indeed produce harmful effects, from the point of view of the planet it would make no difference to adopt a more egalitarian economic system if we were still to have fossil fuel as our main source of energy. An egalitarian economic system, he posits, could be even more harmful in a society fueled by fossil sources of energy, since more people could emit polluting gases into the environment, and capitalism, in reproducing misery in order to produce wealth for few, keeps emissions "low", he adds, with an ironic tone. He does not endorse capitalism, it should be noted; he only points to the inefficacy of the main energy source we currently use.

In this context of thinking the implications of the Anthropocene, Haraway (2016) invites us to think this moment when humans become ethically responsible for so many other species and bodies and things, and she invokes Virginia Woolf's injunction in Three Guineas (first published in 1938), where the latter replies to a fictitious letter from a member of the government. In the letter, the politician asks Woolf how women can aid in the prevention of war. For our current moment, the question can be translated into "how can we improve this situation we have put ourselves in, where climate change threatens to end with innumerous lives on Earth, including our own?" To this question, one could entertain the idea that Woolf would give the same answer:

Think we must. [...] Let us never cease from thinkingwhat is this 'civilization' in which we find ourselves? What are these ceremonies and why should we take part in 
them? What are these professions and why should we make money out of them? Where in short is it leading us, the procession of the sons of educated men? (Kindle edition)

So let us think in the Humanities, and let us think through literature at a time when, as Haraway puts it, we are struggling to reach deep until we extract the last calorie of fossil fuel. Why should one take part in these ceremonies of destruction of ourselves, of countless other species and of the environments? Where is this wild capitalism, this "procession of the sons of educated men", as Woolf puts it, leading us? So, think we must, and the humanities have been producing interesting thoughts and coming up with ways of thinking a world that is now marked by anthropogenic changes. Intersections among ecofeminisms, material feminisms, posthuman and nonhuman theories have been outpouring with useful working terms and notions for scholars to engage in. Scholars, thinkers and literary writers have, in fact, long engaged with the issue of threats to the environment.

When the term "Anthropocene" was first suggested by Paul J. Crutzen in 2000, geologists took it with a grain of salt (ZALACIEWICZ, 2014). After all, they are used to dealing with geological forces that yield effects of such unimaginable magnitude that it was hard to believe humans could produce real impacts on the Earth. Crutzen (2014) explains in an interview that the commonly-held view among scientists in the 1970s was that nature was too big and humankind too small, so "scientists in general did not show much interest in the environment then" (p. 31). It is interesting to note that while scientists were thinking humans too small, ecofeminists and writers such as Ursula K. Le Guin were already attuned to humanity's impacts on nature. A noted ecofeminist scholar, Greta Gaard (1993), has been for at least three decades articulating theory on this ecological front. She puts forward that ecofeminism is a theory that borrows from various strands of feminist studies and activism, and cites some of its origins: "peace movements, labor movements, women's healthcare, and the anti-nuclear, environmental, and animal liberation movements" (p. 1). She continues, arguing that

[d]rawing on the insights of ecology, feminism, and socialism, ecofeminism's basic premise is that the ideology which authorizes oppressions such as those based on race, class, gender, sexuality, physical abilities, and species is the same ideology which sanctions the oppression of nature. Ecofeminism calls for an end to all oppressions, arguing that no attempt to liberate women [...] will be successful without an equal attempt to liberate nature. Its theoretical base is a sense of self most commonly expressed by women and various other 
nondominant groups-a self that is interconnected with all life. (p. 1)

Gaard explains that this notion of a self that is interconnected with all life works in direct opposition to one of the main working definitions of patriarchy and of the nature/ culture dichotomy: the notion that the self/other are separate, the atomistic view of oneself as independent from others and things. This call for a notion of interconnection, intra-action, and assemblage is also found in the recent works of Karen

5 Not discussed in this paper. For Barad's work on intra-connection, see Meeting the Universe Halfway: Quantum Physics and the Entanglement of Matter and Meaning. Duke UP, 2007

${ }^{6}$ Déborah Danowski and Eduardo Viveiros de Castro (2014) list and briefly discuss the nine biophysica processes: climate change, acidification of the oceans, stratospheric ozone depletion, fresh water use, loss of biosphere integrity, phosphorus and nitrogen flows to the biosphere and the oceans changes in the uses of land, chemical pollution, atmospheric aerosol loading.
Barad $^{5}$, and Jane Bennett, echoing an ecofeminist articulation.

One of the most prominent subjects in the debate on the Anthropocene is climate change, and perhaps because it is one of the processes whose safety lines we, as humans, have caused to cross among the nine biophysical processes that must operate within safety boundaries for many forms of life on Earth to thrive ${ }^{6}$. In keeping with the argument that climate change is at the forefront of Anthropocene debates, Jedediah Purdy, in After Nature (2015), claims that the "Anthropocene is, in important ways, a slogan for the age of climate change" (p. 2), since the transition from the Holocene into this new epoch is still under discussion. The Anthropocene is, in other words, a working term to address the anthropogenic changes to the Earth. Climate change, Eduardo Viveiros de Castro and Débora Danowski (2014) show, has profound impacts in the way we live and envision future lives on Earth. The disruption of climate can result in involuntary displacements due to superstorms and sea level rise, water shortage, food shortage, rise in temperatures beyond our capacity to adapt, and more. On this note, Heather Eaton and Lois Ann Lorentzen (2003), in the introduction to Ecofeminism and Globalization, argue that although "ecofeminism" is an umbrella term for a number of epistemological approaches related to women and nature, three claims are central to ecofeminist debates in the context of climate change and environmental destruction. First, they demonstrate, based on reports issued by The United Nations, that women are the most affected victims of environmental destruction, and as the level of poverty increases, so does the probability and weight of impact increase. Ecofeminists working within this claim, which they call the "empirical claim," examine "sociopolitical and economic structures that restrict many women's lives to poverty, ecological deprivation, and economic powerlessness" (p. 2). The second claim is what they term the "conceptual claim," and is connected to Western culture's tendency to conflate women with nature, thus relegating women to the space of the body and men to the abstract space of the mind, a claim that is well explored 
7 See Terry Gifford, 2014, p. 26 Peter Barry, 2002, p.252; Greta Gaard, 2014, p. 297, Stacy Alaimo, 2008, p. 237. in the feminist and ecofeminist literature. The third and probably the most controversial claim, because it is a claim and a proposition to "inhabit the belly of the monster," as Haraway would probably put it, is the "epistemological claim." Eaton and Lorentzen tease out from the women and nature connection a question: "[s]ince environmental problems affect women most directly isn't it possible that women possess greater knowledge and expertise that could prove useful in finding solutions to pressing environmental problems?" (p. 2-3). They acquiesce that most ecofeminists see the women and nature connection as based not on essence but on cultural constructs, and they propose that, in being women the most affected group in environmental disasters, are they not epistemologically privileged when it comes to addressing the problem? They argue that some ecofeminists, however, see this epistemological privilege as "more than a pragmatic claim" (p. 3), suggesting that women are really closer to nature/earth because they possess "inner traits of caring, community building, nonviolence, and Earth sensitivity" (p. 3). Eaton and Lorentzen do not align with this latter claim, though, but aim to explore the former, which is much aligned with the deconstruction of not only the connection that is often made between women and nature, but also the nature/culture dichotomy, which is, as many theorists argue, one of the central concerns of ecocriticism?

In discussing ecofeminism, Gaard (1993) calls attention to a factor that is present in Jane Bennett's (2010) political project in Vibrant Matter. While Gaard argues that "a failure to recognize connections can lead to violence, and a disconnected sense of self is most assuredly at the root of the current ecological crisis" (p. 2), Bennet claims that the Anthropocene represents, for her, an "opportunity to rethink things" ( $p$. viii) and invites us to engage in a more sustainable fashion with lively things and vibrant matter. The Anthropocene, as the moment when we become (officially) responsible for the results of our actions, for the engagements we choose to make with matter and the consequences of these engagements, is a moment when an invitation such as the one made by Bennett makes sense.

Bennet works with a guiding question that has ethical implications: "How would political responses to public problems change were we to take seriously the vitality of (nonhuman) bodies?" (2010, p. viii), and she defines vitality as the capacity of things (and she includes everything under "things": storms, metals, edibles, commodities, and so on) "not only to impede or block the will and designs of humans but also to act as quasi agents or forces with trajectories, propensities, or tendencies of their own" (p. viii). Bennett believes that if we give more credit to the force of things 


\footnotetext{
${ }^{8}$ The idea of "specific configurations" also appears in Haraway (2016) when she draws the following conclusion from Thom van Dooren's work: "Nobody lives everywhere: everybody lives somewhere. Nothing is connected to everything everything is connected to something" (35).
}

instead of taking them as inert while we (humans) hold all vitality, we may be politically more ethical towards things; our consumption habits might change, and we may see the litter we produce as "lively and potentially dangerous matter" (p. viii). She suggests a working term, which is not hers but Bruno Latour's, that of things as "actants". An actant, she explains, "is a source of action that can be either human or nonhuman; it is that which has efficacy, can do things, has sufficient coherence to make a difference, produce effects, alter the course of events" (p. viii). An actant can modify other entities and they can be of any size, meaning that it can also be either too small or too fast to be classified by us as a "thing". But it is, nonetheless, a "thing", an effect-producing body. Bennet sees in this word conceptualized by Latour the creation of a vocabulary that addresses the fact that things that we often deem as inert are indeed vibrant matter, and in doing so an effort is made to conceptualize the notion of "distributive agency" (p. ix), where the world is not shaped by us, but by the whole of humans and nonhumans in specific configurations. ${ }^{8}$ Among the goals that Bennett has and which she explores in Vibrant Matter are a) to shed a more positive light on the ontologies of vibrant matter, b) to trouble the binaries of life/matter, will/determination, human/animal, and organic/inorganic, and to c) "sketch a style of political analysis that can better account for the contributions of nonhuman actants" (p. x).

Bennett's reasons for exploring the vitality of nonhuman and not-quite-human things is quite compelling, as she argues that her "hunch is that the image of dead or thoroughly instrumentalized matter feeds human hubris and our earthdestroying fantasies of conquest and consumption" (2010, p. ix). The epistemological exercise proposed by Bennett is paramount for the Anthropocene, since it brings human and nonhuman bodies to the same plane and allows for the development of ethical approaches to matter with this more horizontal configuration of the world in mind. Aside from that, it has the potential of making one feel as part and parcel of what Haraway (2008) calls "queer confederacies" when she shows how utterly dependent on the confederation among other people, microbes, organic and inorganic life we all are. Haraway traces organic life from its beginning and shows that a process of "complexification" could only take place within these confederacies, with the exchange, mutation, collaboration, and resistance of things - organic and not to reach random results. Adding to this argument, Haraway, in a recent article (2015), makes a genial remark when she puts forth that: "[n]o species, not even our own arrogant one pretending to be good individuals in so-called modern Western scripts, acts alone; assemblages of organic species 
and of abiotic actors make history, the evolutionary kind and the other kinds too" (p. 159).

The articulations that connect most of the abovementioned aspects on the Anthropocene, climate change, feminism, ecocriticism, material feminisms and ecofeminist debates can be grouped under the "nonhuman turn" set of concerns, since implicit in their goals is the troubling of dichotomies that have for so long justified the oppressions of women, of nature, and of innumerous nonhuman bodies and things. This turn, as well the other "turns" related to it, such as the ontological and the posthuman, Richard Grusin (2015) explains, aims at "decentering the human in favor of a turn toward and concern for the nonhuman, understood variously in terms of animals, affectivity, bodies, organic and geophysical systems, materiality, or technologies" (Kindle edition). Grusin calls attention to the fact that almost all challenges we face in current times are related to our "engagement with nonhumans" (Kindle edition), and he lists a few of them: climate change and its effects, genocide, famine, biotechnology, privacy and intellectual property, among others. Having this in mind, he argues, there may be no better time for us to think our engagement with the nonhuman. One could do this, for instance, by thinking through literature.

Chinua Achebe, in the piece entitled "What Has Literature Got to Do With It?" (1990, first published in 1988), in analyzing an economic crisis in Nigeria, demonstrates how having an expert deal with a crisis, a technical expert, neither necessarily solves the crisis nor does he "absolve the rest of us from thinking" (p. 176). In other words, Achebe claims that an expert can only do so much. He adds that one does not need to be an expert to identify that something is wrong and to articulate what can be done to improve the situation one has at hand. "The cry all around us is for more science and less humanities" (p. 180), Achebe wrote in 1988, but stories, he shows, were here first (or was it people?, he plays with the reader), and are still an important tool for understanding and thinking the world. "People create stories create people; or rather, stories create people create stories" (p. 182, emphasis in the original), Achebe says, and Haraway (2015) echoes this play of words by saying that "[i]t matters which stories tell stories, which concepts think concepts" (p. 160). Haraway and Achebe are saying similar things, in different words: the stories we tell produce effects, and literature, Achebe and Haraway show, is entangled with change. It may lend support to maintaining the status quo, yes, but it can also lend itself to produce, as Achebe says, the "kinetic energy necessary for social transition and change" (p. 187). 
${ }^{9}$ For an enlightening discussion on the movement from epistemology to ontology in feminist theory, see Susan Hekman's "Constructing the Ballast: an Ontology for Feminism", in Material Feminisms, edited by Stacy Alaimo and Susan Hekman. Indiana UP, 2008; and Claudia Junqueira de Lima Costa's "O estudos culturais na encruzilhada dos feminismos materiais e descoIoniais," in Estudos de Literatura Brasileira Contemporânea, n. 44, p. 79-103, jul./dec. 2014.
Joanna Zylinska (2014) and Bennet (2015) add to this chorus with their arguments on the role of narratives. For Zylinska, narratives help stabilize certain ethical values that may be of use for us who are facing human-caused impending disasters, as they have, she claims, "a performative nature: they enact and not just describe things" (p. 11). Bennet, reasoning along similar lines, calls texts "special bodies". For her, literary objects, like all objects, are nonhuman agents. The ability of a text to guide the reader to "something more" is the capacity of what she calls "a distributive network of bodies: words on the page, words in the reader's imagination, sounds of words, sounds and smells in the reading room, [...] all these bodies co-acting are what do the job" (Kindle edition). Bennet's argument that texts are bodies that can serve as vehicles to lead us toward more acute human perception, and to things that are not endowed with "wordiness", such as objects, plants, and trash, to name a few, is interesting because it decenters language while using it as a vehicle to something other than itself. This, one may add, is also a central concern in nonhuman theories, that of the movement from epistemology to ontology?

Finally, some words on Haraway's alignment with Le Guin's carrier bag theory of fiction and on Le Guin's theory itself. For Haraway (2008), the act of telling stories is to engage in world-building. The stories we tell matter, her reasoning tells us, so it is to no one's surprise that many times in her theory she draws from Le Guin's Carrier Bag Theory of Fiction. In this theory, Le Guin (1996, first published in 1986) exposes her preference for narratives that are more concerned with the "collecting" of small things, of things that can be carried in a bag, instead of with narratives that focus on the predatory journey of the hero. All of us, Le Guin claims, have

heard all about all the sticks and spears and swords, the things to bash and poke and hit with, the long, hard things, but we have not heard about the thing to put things in, the container for the thing contained. That is a new story. That is news. (p. 151)

And it is not news, she shows. It can actually be considered be very old news, as Le Guin brings a piece of anthropological study by Elizabeth Fisher that suggests that the first cultural device was, most probably, a recipient in which to put things in: indispensable things such as food, energy, babies, and recipients to carry these things home in. The home itself, she adds, is a recipient. So the bag makes sense to Le Guin, and it makes sense to Haraway, and it makes to the arguments that a number of scholars are pursuing in this moment when it seems crucial to tell stories that may add to the debates on climate change, global 
warming, mass extinction, displacement and other issues related to the Anthropocene. In other words, in the context of the Anthropocene, whether one addresses it as a geological epoch or as a working term to think the anthropogenic changes humanity has promoted on this Earth, narratives that are more concerned with the collection of and ethical engagement with things seems to be a good starting place for the development of research. Literature and the material which it refers to, books, can be taken as containers where many authors engages with thinking the world we are living in. A book, Le Guin puts it, "holds words. Words hold things. They bear meanings. A novel is a medicine bundle, holding things in a particular, powerful relation to one another and to us" (1996, p. 153). If one is to make a connection between Le Guin's and Haraway's articulations, one could even say that a book holds not only words, but worlds, the possibility of worlds, and humanities scholars may as well tackle these materials (literature, books) in order to establish the relation between these worlds and our world.

Grusin (2015) reminds us that Western literature has for very long dealt with the nonhuman in a way that reflects a concern for humans' relation with nature, citing Thoreau, Whitman, Melville, among others. Many contemporary writers have added to the concern for the nonhuman the issue of climate change, the impacts of the consumption of meat, the use of genetically engineered seeds and agrochemicals, and environmental disasters. Ruth Ozeki, in A Tale for the Time Being (2013), for instance, explores the effects of the 2011 tsunami that hit Japan when a character named Ruth finds a diary on the shores of Canada, on the other side of the Pacific Ocean. In the diary, an American-Japanese teenager narrates her ponderings on life and suicide. In the midst of the narrative, the author discusses things such as the ocean gyres, the Pacific garbage patch, the impact of the use of fossil fuel on the Earth and other human nature-disrupting practices. In her earlier book, All Over Creation (2003, first published in 2002), Ozeki exposes the effects of GMOs on the lives of two families who live off the land. She presents the reader with forms of resistance that can take unlikely shapes, as in the case of the "seeds of resistance", an anti-GM activist group that does public interventions and maintains a website of erotic videos (the actress of the videos normally covers herself with vegetables and uses them for pleasure) to fund their activist travels across the United States. There is also Helen Macdonald who, in the memoir $H$ is for Hawk (2015), blurs the boundaries between human and nonhuman in her encounter with a goshawk named Mabel, whom Macdonald trains in the wake of her father's death. The author shows how it is more comfortable at times for her to relate to a bird of prey 
than to her human counterparts. Another example of the encounter between human and a changing landscape in the Anthropocene is Robert MacFarlane's The Old Ways: A Journey on Foot (2012), where he narrates his walks while thinking the effect of humans on the Earth.

The genres of speculative and science fiction are also fertile terrains to ponder the waning boundaries between the human and the nonhuman and the ways in which human practices are disrupting the natural world almost to the point of no return. Jeanette Winterson's The Stone Gods (2007) is an interesting thought-experiment that begins with a tech-driven society of the past and the terraforming of our Earth. The message one gets is clear: what we are doing here now, on Earth, we have already done on other planets that we have once called home. Margaret Atwood's MaddAddam Trilogy (which comprises Oryx and Crake, 2004; The Year of the Flood, 2009; and MaddAddam, 2014) also paints the picture of a post-apocalyptic world that, similarly to All Over Creation, deals with genetic engineering, but takes it to the extreme, and those who manage to survive must share the world with new, strange creatures that set doubt on what is natural, human, nonhuman. Station Eleven, by Emily St. John Mandels (2015), offers a different scenario that takes the reader to similar conclusions. After a flu spreads across the globe, killing off most of the world's population, what becomes clear is that nature quickly takes over what we tend to see as human, and the balance of power that once seemed so clear (man over nature) is overturned in plain sight. What I hope to have shown with these examples is that literature, like the humanities, is outpouring with works that warn, ponder on, and speculate what is happening and what might happen if we continue to overlook the practices that have led the world to enter (according to human parameters, of course) the Anthropocene Epoch. Geologists will continue on dealing with and analyzing rocks. Humanities scholars have, I would argue, very rich and interesting investigation materials to work on as well, and in doing so one might gain more insight not only into what ethics are possible and desirable for human and nonhuman interactions in the present and future, but also into the cultural practices that have led us into the Anthropocene in the first place.

\section{Works Cited}

ACHEBE, Chinua. Hopes and Impediments. Anchor Books, 1990.

ALAIMO, Stacy; HEKMAN, Susan. "Introduction: Emerging Models of Materiality in Feminist Theory". In: Material Feminisms. Indiana University Press, 2008. 
ATWOOD, Margaret. The MaddAddam Trilogy: Oryx and Crake; The Year of the Flood; MaddAddam. Vintage Canada, 2013.

AUSTIN, Whitney J.; HOLBROOK, John M.. "Is the Anthropocene an issue of stratigraphy or pop culture?" GSA Today, v. 22, n. 7, p. 61-62, July 2012.

BARRY, Peter. Beginning Theory: An Introduction to Literary and Cultural Theory. Manchester University Press, 2002.

BENNETT, Jane. Vibrant Matter: Political Ecology of Things. Duke University Press, 2010

"Systems and Things On Vital Materialism and ObjectOriented Philosophy". In: GRUSIN, Richard (Ed). The Nonhuman Turn. University of Minnesota Press, 2015.

CHAKRABARTY, Dipesh. "The Anthropocene Project. An Opening." YouTube, uploaded by HKW Anthropocene, 21 Jan. 2013, https://www.youtube.com/watch?v=svgqLPFpaOg.

COSTA, Claudia de Lima. "Os estudos culturais na encruzilhada dos feminismos materiais e descoloniais." Estudos de Literatura Brasileira Contemporânea, n. 44, p. 79-103, 2014.

CRUTZEN, Paul J. "We aren't doomed? An Interview with Paul J. Crutzen". In: Welcome to the Anthropocene: The Earth in Our HANDS. DEUTSCHES MUSEUM, 2014.

DANOWSKI, DÉBORA; VIVEIROS DE CASTRO, Eduardo. Há Mundo por Vir? Ensaio Sobre os Medos e os Fins. Cultura e Barbárie, 2014.

EATON, Heather; LORENTZEN, Louis Ann. Ecofeminism and Globalization: Exploring Culture, Context, and Religion. Rowman \& Littlefield Publishers, 2003.

GAARD, Greta. "Living Interconnections with Animals and Nature". In: Ecofeminism: Women, Animals, Nature. Temple University Press, 1993.

"Mindful New Materialisms: Buddhist Roots for Material Ecocriticism's Flourishing". In: IOVINO, Serenella; OPPERMANN, Serpil (Eds.). Material Ecocriticism. Bloomington: Indiana University Press, 2014.

GIFFORD, Terry. "Pastoral, Anti-Pastoral, and Post-Pastoral". In: WESTLING, Louise (Ed.). The Cambridge Companion to Literature and the Environment. Cambridge: Cambridge University Press, 2014.

GRUSIN, Richard. "Introduction." In: GRUSIN, Richar (Ed.). The Nonhuman Turn. Minneapolis: University of Minnesota Press, 2015.

HARAWAY, Donna. "Otherwordly conversations, Terran Topics, Local Terms." In: ALAIMO, Stacey; HEKMAN, Susan (Eds.) Material Feminisms. Bloomington: Indiana University Press, 2008.

"Anthropocene, Capitalocene, Plantationocene, Chthulucene: Making Kin". Environmental Humanities, v. 6, p. 159-165, 2015. 
"Sowing Worlds: A Seed Bag for Terraforming with Earth Others". In: GREBOWICZ, Margret; MERRICK, Helen (Eds.). Beyond the Cyborg: Adventures with Donna Haraway. New York: Columbia University Press, 2013a.

.When Species Meet. Minneapolis: University of Minnesota Press, 2013b.

"Donna Haraway." YouTube, uploaded by Os Mil Nomes de Gaia, 24 Sep. 2014, https://www.youtube.com/ watch? $v=1 \times 0$ oxUHOIA8.

"Staying with the Trouble: Anthropocene, Capitalocene, Chthulucene." In: MOORE, Jason W. (Ed.). Anthropocene or Capitalocene? Nature, History, and the Crisis of Capitalism. Oakland, CA: PM Press, 2016.

IOVINO, Serenella; OPPERMANN, Serpil. "Introduction: Stories Come to Matter". In:___ (Eds.). Material Ecocriticism. Bloomington: Indiana University Press, 2014.

LE GUIN, Ursuka K. "The Carrier Bag Theory of Fiction". In: GLOTFELTY Cheryll ; FROMM Harold (Eds.). The Ecocriticism Reader: Landmarks in Literary Ecology. Athens, GA: The University of Georgia Press, 1996.

MACDONALD, Helen. $\boldsymbol{H}$ is for Hawk. New York: Grove Press, 2015.

MACFARLANE, Robert. The Old Ways: A Journey on Foot. New York: Penguin Books, 2012.

MANDELS, Emily St. John. Station Eleven. New York: Vintage Books, 2015

OZEKI, Ruth. A Tale for the Time Being. New York: Viking, 2013. . All Over Creation. New York: Penguin Books, 2003.

PURDY, Jedediah. After Nature: A Politics for the Anthropocene. Cambridge: Harvard University Press, 2015.

WINTERSON, Jeanette. The Stone Gods. London: Hamish Hamilton, 2007.

WOOLF, Virginia. Three Guineas. Fort Washington, PA: Harvest Books, 1938.

ZALACIEWICZ, Jan. The Earth After Us. Oxford: Oxford University Press, 2008.

. "The Human Dimension in Geological Time". In: Welcome to the Anthropocene: The Earth in Our Hands. Deutsches Museum, 2014.

. et al. "When did the Anthropocene begin? A midtwentieth centuryboundary level is stratigraphically optimal." Quaternary International, v. xxx, p. 1-8, 2014.

. et al. "Response to Autin and Holbrookon: Is the Anthropocene an issue of stratigraphy or pop culture?" GSA Today, v. 22, p. 21, August 2012.

ZYLINSKA, Joanna. Minimal Ethics for the Anthropocene. London: Open Humanities Press, 2014. 
[Recebido em 01/08/2016 e aprovado em 12/01/2017]

\begin{abstract}
O antropoceno (e) (n)as Humanidades: possibilidades para os Estudos Literários Resumo: O artigo discute o conceito do Antropoceno e examina, brevemente, seu significado dentro das ciências geológicas para, então, considerar alguns dos desdobramentos teóricos do termo dentro das humanidades. Ao final, o trabalho se propõe a relacionar as demandas que o Antropoceno apresenta como Época geológica (em que o humano se coloca como força geofísica modificadora de sistemas biofísicos da Terra) aos estudos literários como um possível campo de articulação teórica que pode vir a acrescentar ao debate sobre esse momento histórico em que mudanças climáticas, deslocamentos forçados, extinções em massa de diversas espécies e outros temas urgentes se fazem presentes.

Palavras-chave: Antropoceno; Mudanças Climáticas; Humanidades; Estudos Literários.
\end{abstract}

Melina Pereira Savi (melsavi@gmail.com) é doutoranda em Estudos Culturais e Literários pelo Programa de Pós-Graduação em Inglês da Universidade Federal de Santa Catarina. Bolsista da CAPES, realiza pesquisa de doutorado intitulada Ursula K. Le Guin and the Anthropocene: Otherworldly Literature for Nonhuman Times, sob a orientação da Profo Claudia de Lima Costa. 